\title{
MENGENALI RAMBU LALU LINTAS MENGGUNAKAN METODE HOG DAN KNN
}

\author{
Agnes Dirgahayu Palit \\ Fakultas Teknik, Jurusan S1 Teknik Informatika, \\ Universitas Telkom \\ J1. Telekomunikasi No. 01, Terusan Buah Batu, Bandung 40257 Indonesia \\ e-mail : adirgapalit@gmail.com
}

\begin{abstract}
Abstrak
Kota-kota besar pasti tidak lepas dengan penggunaan rambu lalu lintas untuk meningkatkan keselamatan pengguna jalan. Rambu lalu lintas dirancang untuk membantu pengemudi untuk mencapai tujuan mereka dengan aman, dengan menyediakan informasi rambu yang berguna. Meskipun demikian, hal yang tidak diinginkan dapat terjadi ketika informasi yang tersimpan pada rambu lalu lintas tidak diterima dengan baik pada pengguna jalan. Hal ini dapat menjadi masalah baru dalam keamanan berkendara. Dalam meminimalisasi masalah tersebut, dapat dibuat suatu teknologi yang mengembangkan sistem yang mengidentifikasi objek rambu lalu lintas secara otomatis yang dapat menjadi salah satu alternatif meningkatkan keselamatan berkendara, yaitu Traffic Sign Recognition (Sistem Rekognisi Rambu Lalu Lintas). Sistem ini menggunakan metode Histogram of Oriented Gradient (HOG), untuk ektraksi ciri citra, dan $K$ Nearest Neighbour (KNN) untuk mengklasifikasikan citra rambu lalu lintas. Sehingga dapat dianalisa bagaimana Sistem dapat mengenali citra yang merupakan objek rambu lalu lintas? Serta bagaimana performansi akurasi sistem. Diharapkan dengan adanya paduan metode-metode tersebut dapat dilihat bagaimana sistem merekognisi rambu lalu lintas. Dari hasil pengujian performansi sistem dengan nilai $\mathrm{k}=3$, diperoleh akurasi sistem $79.4444 \%$.
\end{abstract}

Kata kunci : ekstraksi ciri, klasifikasi, $H O G, K N N$.

\section{Abstract}

The big cities must not be separated by the use of traffic signs to improve road safety. Traffic signs designed to help drivers to reach their destination safely, by providing useful information signs. Nonetheless, undesirable things can happen when information stored in the traffic signs are not received well on the road. It can be a new problem in road safety. In minimizing the problem, can be made of a technology that is developing a system that identifies an object traffic signs automatically which can be one alternative to improve driving safety, the Traffic Sign Recognition. The system uses a method Histogram of Oriented Gradient (HOG), for the feature extraction of image characteristics, and K-Nearest Neighbor (KNN) to classify traffic signs image. So, it can be analyzed how the system can detect and recognize the image which is the object of traffic signs? And how the accuracy of the system performance. Expected by the blend of these methods can be seen how the system detects and merekognisi traffic signs. From the results of performance testing system with a value of $k$ $=3$, acquired $79.4444 \%$ system accuracy.

Keyword : feature extraction, classification, HOG, KNN

\section{Pendahuluan}

Kota-kota besar pasti tidak lepas dengan penggunaan rambu lalu lintas untuk meningkatkan keselamatan pengguna jalan. Rambu lalu lintas dirancang untuk membantu pengemudi untuk mencapai tujuan mereka dengan aman, dengan menyediakan informasi rambu yang berguna (Victor Adrian Prisacariu, 2010). Rambu lalu lintas dirancang dan di tempatkan di tempat yang gampang untuk dilihat sedemikian sehingga mudah untuk dilihat pengguna jalan (MP N. B., 2011). Rambu lalu lintas memberikan informasi visual seperti mengemudi dijalur yang tepat, pembatasan kecepatan, menghindari rintangan, jalur untuk pejalan kaki, arah tujuan, akses jalan, kondisi lalu lintas saat ini, dan lain-lain (Safat B. Wali, 2015). 
Meskipun demikian, hal yang tidak diinginkan dapat terjadi ketika informasi yang tersimpan pada rambu lalu lintas tidak diterima dengan baik pada pengguna jalan. Sebagai contoh apabila rambu jalan yang terlewat atau rambu tersebut salah artikan, bahkan mungkin diabaikan. Dari hal tersebut kecelakaanpun bisa terjadi. Terlihat bahwa hal tersebut dapat mengakibatkan akibat yang cukup fatal yang dapat merenggut nyawa manusia. Berdasarkan statisktik terkini menunjukkan bahwa lebih dari $98 \%$ kecelakaan mobil terjadi karena pengemudi terganggu (Victor Adrian Prisacariu, 2010).

Saat ini, teknologi yang mengembangkan sistem identifikasi objek rambu lalu lintas secara otomatis dapat menjadi salah satu alternatif, dan bahkan menjadi terobosan baru dalam pengembangan keselamatan berkendara. Sebab, meningkatkan keamanan lalu lintas adalah tujuan yang penting pada sistem transportasi pintar (Huaping Liu, 2014). Sehingga dibutuhkan cara baru yang lebih efektif untuk pemrosesan objek rambu lalu lintas ke media elektronik. Salah satunya adalah dengan membangun Traffic Sign Recognition (Sistem Rekognisi Rambu Lalu Lintas).

Traffic Sign Recognition, merupakan sistem yang dibangun untuk mengenali kelompok-kelompok pixel citra dari suatu gambar rambu lalu lintas yang didapatkan, dengan mengenali kelompok-kelompok pixel mana yang merupakan objek rambu lalu lintas, dan objek mana yang bukan rambu lalu lintas. Sistem ini dapat membantu pengendara mobil untuk memahami bahasa visual dan menginformasikan kondisi dari rambu lalu lintas (Safat B. Wali, 2015). Di beberapa negara seperti Amerika, Jerman, Switzerland, Malaysia, dan negara maju lainnya, pengembangan Traffic Sign Detection and Recognation sudah banyak dikembangkan (Andreas Mogelmose, 2015) (Markus Mathias, 2013). Sebagai contoh di Switzerland, pengembangan sistem tersebut pada kendaraan mobil, dengan meletakkan sebuah diferensial GPS yang terhubung melalui RS232 serial port, sepasang kamera digital disinkronkan terhubung melalui port FireWire dan sensor nirkabel 802.15.4 ZigBee Mote digunakan sebagai penerima dalam sistem komunikasi I2V (Miguel A. Garcia-Garrido, 2012).

Khusus pada tugas besar kali ini, sistem rekognisi rambu lalu lintas akan menggunakan inputan pixel foto. Dengan alur program seperti pada bagan 1 .

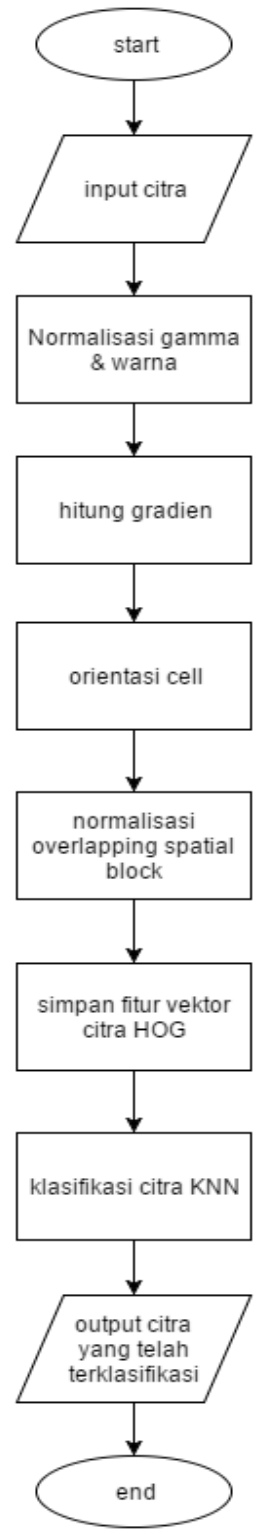

Gambar 1 : Ikhtisar konsep dalam mengenali citra Rambu Lalu Lintas

\section{Penelitian Terkait}

Citra rambu lalu lintas berperan sebagai objek yang esensial dalam sistem deteksi dan rekognisi rambu lalu lintas. Beberapa metode yang telah digunakan dalam penelitian terdahulu untuk deteksi dan rekognisi rambu lalu lintas antara lain Histogram 
of Orient Gradient (HOG) untuk ekstraksi ciri. Linear Discriminant Analysis (LDA), Sparse Representation based Linier Projection (SRLP), Iterative Nearest Neightbors based linier Projection (INNLP) untuk reduksi dimensi citra. Dan Nearest Neightbor Classifier (NN), Sparse Representation-based Classifier (SRC), Iterative Nearest Classifier (INNC), untuk klasifikasi citra rambu lalu lintas (Markus Mathias, 2013).

Dari paduan penggunaan metode di atas, dalam merekognisi citra rambu lalu lintas, rata-rata sudah menghasilkan ukuran performansi di atas $80 \%$. Misalnya paduan metode HOG, LDA dan NN dengan memproses Dataset German Traffic Sign Detection Benchmark (GTSD) menghasilkan akurasi $96.97 \%$ dengan waktu proses pembelajaran data latih (training time) none. Dan waktu tes data tes (testing time) $\sim 5 \mathrm{~s}$ (Markus Mathias, 2013).

Metode yang memiliki fungsi untuk mengklasifikasikan data antara lain $(K$ Nearest Nightbour) KNN. Metode ini merupakan salah satu teknik classifier memiliki adalah relatif tidak terpengaruh dari error dari data dan juga dapat digunakan dengan kumpulan data dengan jumlah besar (Hanifa Vidya Rizanti, 2010).

Dengan menggabungkan kedua metode tersebut diharapkan sistem yang akan dibangun dapat mempermudah mengenal informasi dari rambu lalu lintas disekitar kendaraan yang digunakan dengan cepat dan akurat, dan dengan performansi akurasi dan waktu proses program yang baik.

\section{Data SeT}

Dataset yang akan diolah adalah Traffic Sign Dataset SCIA 2011 oleh Computer Vision Laboratory Department of Electrical engineer at Linköping University. Terdiri dari 3488 citra rambu lalu lintas. Pengambilan citra sejauh $350 \mathrm{~km}$ sepanjang jalan raya Swedia. Dengan menggunakan kamera berwarna 1.3 mega-pixel, Point-Grey Chameleon, ditempatkan di dalam sebuah mobil di dashboard melihat keluar dari jendela depan. Lensa memiliki panjang fokus $6.5 \mathrm{~mm}$, dengan besar sudut 41 derajat bidang pandang. Kecepatan rata-rata di jalan raya yang lebar sekitar $90 \mathrm{~cm} / \mathrm{s}$, yang sesuai dengan ukuran sekitar 50 pixel jika mereka terdeteksi pada jarak sekitar $30 \mathrm{~m}$.

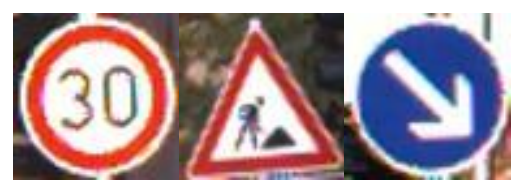

Gambar 2 : sample data train

Label untuk setiap rambu lalu lintas mengandung jenis tanda (penyeberangan pejalan kaki, yang ditunjuk jalur kanan, tidak berdiri atau parkir, prioritas jalan, memberikan jalan, 50 kilometer per jam, atau 30 kilometer per jam). Dengan bentuk rambu, anatara lain, bundar, segitiga, dan diamond. Data latih terdiri atas 671 label dan data tes terdiri atas 180 label. Dengan 40 jenis klasifikasi rambu-rambu.

\section{KAJIAN LITERATUR}

Pada program "Traffic Sign Recognation" digunakan berbagai metode seperti HOG untuk ekstraksi ciri fitur, dan KNN untuk klasifikasi jenis rambu lalu lintas. Maka pada bagian ini akan di bahas kajian literatur terkait metode yang digunakan.

Berikut merupakan ikhtisar dari alur program dalam mengenali citra rambu lalu lintas, bisa dilihat pada gambar 1 .

\section{IV.1 Histogram of Oriented Gradients (HOG)}

HOG digunakan untuk menunjukkan keterangan fitur yang digunakan untuk mendeteksi benda-benda dalam teknologi computer vision dan pengolahan citra. Teknik HOG menghitung kejadian orientasi gradien dalam porsi lokal dari gambar.

Implementasi metode HOG adalah antara lain :

- Membagi gambar menjadi wilayah kecil yang terhubung. Hal tersebut disebut juga dengan sel. Setiap sel menghitung histogram dari arah gradien atau orientasi tepi untuk piksel dalam sel (Intel).

- Setelah itu, setiap sel didiskrit dalam sudut biner sesuai dengan orientasi gradien. Perhitungan gradien diperoleh dengan penyaringan filter 2 dimensi yaitu filter vertikal dan horisontal. 


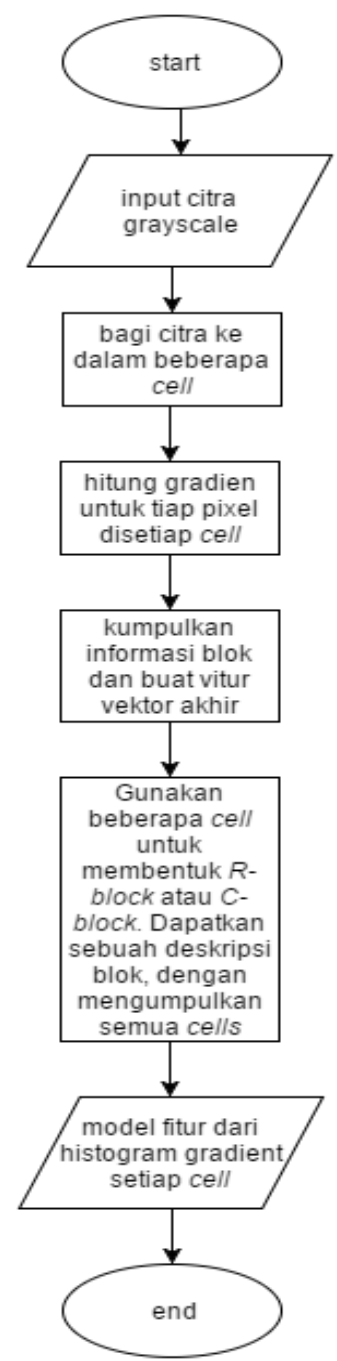

Gambar 3: Ikhtisar proses dari ekstraksi HOG

Dengan menggunakan rumus derivatif parsial untuk fungsi image $f(x, y)$ :

a. Untuk sumbu $\mathrm{x}$ :

$$
\frac{\partial f}{\partial x}=f \frac{(x+h)-f(x-h)}{2 h}
$$

b. Untuk sumbu y:

$$
\frac{\partial f}{\partial y}=f \frac{(y+h)-f(y-h)}{2 h}
$$

Akan di peroleh nilai $\mathrm{x}$ dan $\mathrm{y}$ yang digunakan untuk menghitung gradient :

a. Magnitude (besar gradient): $\mathrm{R}=$

$$
R=\sqrt{x^{2}+y^{2}}
$$

b. Orientasi gradient (dalam sudut):

$$
\theta=\arctan \left(\frac{y}{x}\right)
$$

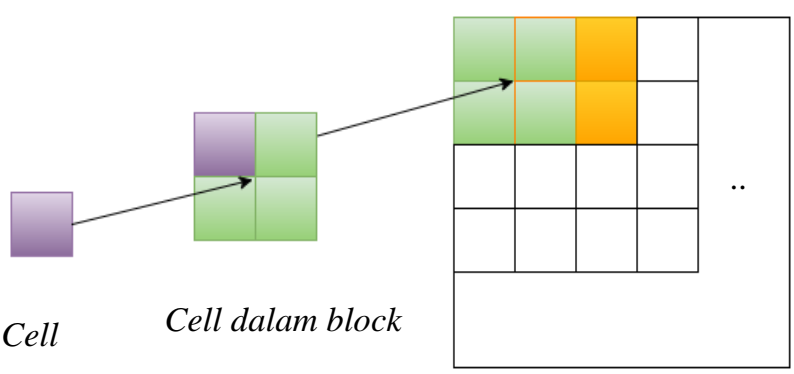

Block yang overlap

Gambar 2 : Cell yang menyusun block

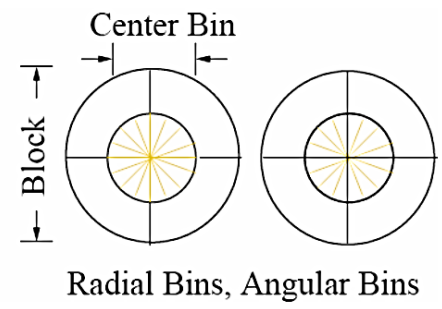

\section{Gambar 4 : Proses Binning}

Pada program, proses binning area citra di bagi menjadi 9 area dengan rata-rata setiap binning memiliki besar sudut juring 20 derajat.

Pixel setiap sel yang ada, berkontribusi pada bobot gradien pada sudut biner yang sesuai. Kelompok sel yang berdekatan dianggap sebagai daerah spasial, hal tersebut disebut sebagai blok. Pengelompokan sel ke dalam blok adalah dasar untuk pengelompokan dan normalisasi histogram.

- Histrogram kemudian di normalisasi membentuk suatu kelompok normalisasi, yang disebut dengan blok histogram, yang juga di kelompok tersebut di himpun dalam beberapa himpunan disebut dengan deskriptor (Intel).

Cara menghitung normalisasi hitogram dalam blok :

1) $\mathrm{L} 1-$ norm : $\mathrm{v}->\mathrm{v} /(\|\mathrm{v}\| 1+$ epsilon $)$;

2) $L_{1}-\operatorname{sqrts} v \rightarrow \sqrt{v /\|v\|_{1}+\varepsilon}$.

3) $L_{2}-$ norm: $v \rightarrow \sqrt{\|v\|_{2}^{2}+\varepsilon^{2}}$ 
4) $L_{2}-$ hys, $L_{2}$ - norm diikuti oleh clipping; dibatasi nilai maksimum dan re-normalisasi (Cahyo Permata).

\section{IV.2 KNN}

Metode K-Nearest Neighbor (k-N) adalah sebuah metode untuk melakukan klasifikasi terhadap objek berdasarkan data yang jaraknya paling dekat dengan objek tersebut. Metode ini merupakan metode yang paling umum digunakan untuk estimasi dan prediksi (Miguel A. Garcia-Garrido, 2012). Keunggulan dari metode KNN ini adalah relatif tidak terpengaruh dari error dari data dan juga dapat digunakan dengan kumpulan data dengan jumlah besar. Namun kekurangan metode ini adalah proses pelaksanaannya lambat.

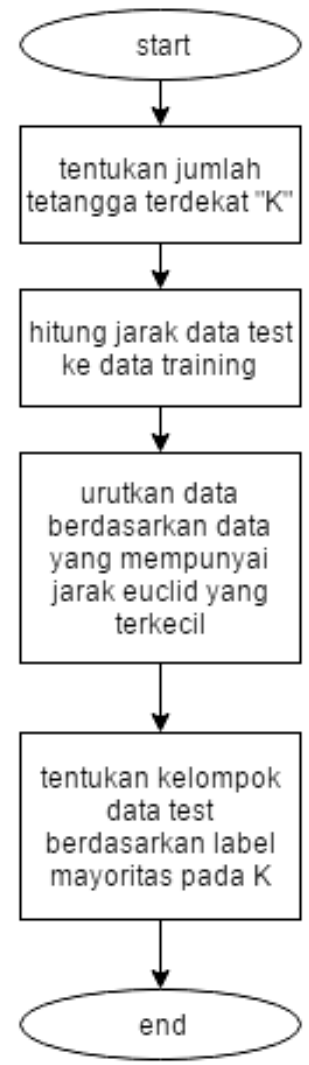

Gambar 5. : Alur proses K-NN

Tujuan dari algoritma k-NN adalah untuk mengklasifikasi objek baru berdasarkan atribut dan training samples. Dimana hasil dari sampel uji yang baru diklasifikasikan berdasarkan mayoritas dari kategori pada k-NN. Pada proses pengklasifikasian, algoritma ini tidak menggunakan model apapun untuk dicocokkan dan hanya berdasarkan pada memori. Algoritma k-NN menggunakan klasifikasi ketetanggaan sebagai nilai prediksi dari sampel uji yang baru. Jarak yang digunakan adalah jarak Euclidean Distance. Jarak Euclidean adalah jarak yang paling umum digunakan pada data numerik. Euclidean distance didefinisikan sebagai berikut (Nobertus Krisandi, 2013):

Persamaan..... (euclidian distance)

$$
\mathrm{D}\left(\mathrm{a}_{\mathrm{i}}, \mathrm{b}_{\mathrm{j}}\right)=\sqrt{\sum_{\mathrm{i}=1}^{n}\left(a_{\mathrm{i}}-b_{\mathrm{i}}\right)^{2}}
$$

Keterangan :

$\mathrm{D}\left(\mathrm{a}_{\mathrm{i}}, \mathrm{b}_{\mathrm{j}}\right)$ : Jarak (Euclidian Distance)

$$
\begin{aligned}
& \left(a_{i}\right) \text { : data a yang ke-i } \\
& \left(b_{i}\right) \text { : data b yang ke-i } \\
& \text { i : } 1,2,3, \ldots . n
\end{aligned}
$$

Algoritma k-NN adalah algoritma yang menentukan nilai jarak pada pengujian data testing dengan data training berdasarkan nilai terkecil dari nilai ketetanggaan terdekat (Miguel A. GarciaGarrido, 2012).

\section{EKSPERIMEN KLASIFIKASI DAN ANALISIS}

Tabel 1. Performansi dan waktu sistem mengolah data train dan testing

\begin{tabular}{llcc}
\hline \hline Fitur & Klasifikasi & Akurasi & Waktu proses \\
\hline \hline HOG & KNN $(\mathrm{K}=1)$ & $76,6667 \%$ & $298.154 \mathrm{~s}$ \\
HOG & KNN $(\mathrm{K}=2)$ & $76,6667 \%$ & $299.667 \mathrm{~s}$ \\
HOG & KNN $(\mathrm{K}=3)$ & $79.4444 \%$ & $304.811 \mathrm{~s}$ \\
HOG & KNN $(\mathrm{K}=4)$ & $78.3333 \%$ & $328.292 \mathrm{~s}$ \\
HOG & KNN $(\mathrm{K}=5)$ & $79.4444 \%$ & $334.313 \mathrm{~s}$ \\
HOG & KNN $(\mathrm{K}=6)$ & $79.4444 \%$ & $309.014 \mathrm{~s}$ \\
HOG & KNN $(\mathrm{K}=7)$ & $77.2222 \%$ & $286.601 \mathrm{~s}$ \\
\hline \hline
\end{tabular}

\section{V.1 Pelatihan}

Pada saat proses pelatihan (training), data latih diproses dengan menggunakan Quad-Core AMD dengan 4 GB RAM. Fitur yang dihasilkan pertama kali ada fitur vektor HOG sebagai model. Citra yang diolah untuk menghasilkan fitur vekttor HOG dimana ambil data set dengan data positif pada matrix_moment.mat. Citra yang diinputkan sudah 
dicrop dengan ukuran 64 x 64 pixel lalu di grayscale. Pada sesi training, dengan script Matlab memakan waktu sampai $273.424 \mathrm{~s}$.

\section{V.2 Pengujian}

Pada waktu testing, citra pada data testing, melewati algoritma KNN. Pada tahap ini di cari jarak euclidian masing-masing fitur vektor HOG data test terhadap fitur vektor HOG data training. Waktu yang di butuhkan adalah 55.7340s.

\section{V.3 Performansi}

Setelah dilakukan proses testing, dilakukan proses pengecekan performansi. Performansi yang diukur ada akurasi dengan membandingkan label hasil class yang dihasilkan proses klasifikasi k-NN dengan label pada data test. Hasil dari pengukuran tersebut terlihat parameter dengan $\mathrm{k}=3$ pada klasifikasi $\mathrm{KNN}$, menghasilkan akurasi dan waktu proses yang paling baik, dengan 143 data hasil klasifikasi dinyatakan sesuai dengan label data test asli yang berjumlah 180 buah label data test. Atau dalam persentasi akurasi = $76,6667 \%$. Dengan lama waktu proses $304.811 \mathrm{~s}$

\section{KESIMPULAN DAN SARAN}

Pada sistem ini, menggunakan dataset Traffic Sign Dataset SCIA 2011 oleh Computer Vision Laboratory Department of Electrical engineer at Linköping University Swedia. Dengan mengimplementasikan kelas yang memiliki bentuk lingkaran, segitiga, dan diamond. Sistem menunjukkan performansi akurasi pada angka $79.4444 \%$.

HOG merupakan metode ekstraksi ciri yang lumayan sering digunakan, namun memang perlu diperhatikan bagaimana cara membagi citra dalam beberapa cell, dana cara pembentukan iterasi block serta proses binning pada metode ini. Hal tersebut juga sebagai saran perbaikkan yang bisa dilakukan apabila akan melakukan penelitian yang serupa.

Pengembangan sistem kedepennya dapat menggunakan metode klasifikasi yang berbeda dan mungkin dapat dilengkapi dengan metode reduksi dimensi setelah proses ekstraksi ciri dilakukan, sehingga didapati tingkat performansi akurasi yang lebih baik.

\section{REFERENSI}

Andreas Mogelmose, D. L. (2015). Detection of US Traffix Sign. IEEE Transactions on Intelligent Transportation Systems, 1.

Cahyo Permata, I. K. (t.thn.). Deteksi Mobil Menggunakan Histogram of Oriented Gradient. (Jurusan Teknik Elektro, Fakultas Teknologi Industri, Institut Teknologi Sepuluh Nopember (ITS)), 2-3.

Hanifa Vidya Rizanti, S. R. (2010). PENGENALAN CITRA ALPHABET BERDASARKAN PARAMETER MOMEN INVARIAN DENGAN METODE CASE-BASED REASONING. Universitas Brawijaya, 1.

Huaping Liu, Y. L. (2014). Traffic Sign Using Group Sparce Coding. Elsevier, 1.

Intel. (t.thn.). Histogram of Oriented Gradients (HOG) Descriptor. https://software.intel.com/enus/node/529070.

Markus Mathias, R. T. (2013). Traffic Sign Recognation - How far are we from the solution? International Joint Conference on Neural Networks (IJCNN 2013), 1.

Miguel A. Garcia-Garrido, M. O. (2012). Complete Vision-Based Traffic Sign Recognition Supported by an I2V Communication System. MDPI(12), 1153.

MP, N. B. (2011). Traffic Signs Policy Paper. Britain: Department for Transport.

Nobertus Krisandi, H. B. (2013). Algoritma k-nearest neighbour dalam klasifikasi data hasil produksi kelapa sawit pada PT. Minamas Kecamatan Parindu. Buletin Imiah Math. Stat dan terapannya (Bimaster), 33-38.

Prisacariu, R. T. (t.thn.). Integrating Object detection with 3D Tracking Towards a Better Driver Assistance System. 2010.

Safat B. Wali, M. H. (2015). Comparative Survey on Traffic Sign Detection and Recognition. http://pe.org.pl/articles/2015/12/8.pdf, 1 .

Victor Adrian Prisacariu, R. T. (2010). Integrating Object detection with 3D Tracking Towards a Better Driver Assistance System. 1. 